\title{
The Development of an Information System for the Solidarity Economy Movement
}

\author{
Alan Freihof Tygel \\ Universidade Federal do Rio de Janeiro \\ Celso Alexandre Souza de Alvear \\ Universidade Federal do Rio de Janeiro
}

\begin{abstract}
This article aims to describe and analyze the development process of Cirandas (http://www.cirandas.net), an information system geared towards the Solidarity Economy community in Brazil. The creation of a virtual community incorporated in a real community permits an analysis of the similarities and differences between both instances of the community.
\end{abstract}

Keywords: Keywords: Community informatics, Community economic development, Social cohesion, Solidarity economy, Social capital. 


\section{Introduction}

This article aims to describe and analyze the development process of Cirandas (www.cirandas.net), an information system geared towards the Solidarity Economy community in Brazil. The development of this system brings to light several issues related to the interaction between a community and an information system. In addition to that, the creation of a virtual community incorporated in a real community permits an analysis of the similarities and differences between both instances of the community.

This article intends to analyze the Cirandas development process, still underway, from the perspective of the interaction between the community in general, the developers, and the designers who also make up part of the community. For such, the article is structured as follows: initially there will be two contextualizations as a way to characterize the objects of study, which are the Solidarity Economy (SE) movement in Brazil and the Cirandas. As to the former, the form of organization, the participants, and a mapping done in 2007 will be reported. As to the latter, the objectives, motivations, and the current state will be detailed.

Following, we will raise and discuss issues that involve SE as a community, and the Cirandas as a related virtual community. An analysis of SE as a community will be done on how the SE community relates to the information system, and on a virtual community created by the system. We will raise issues that will try to relate the Cirandas with possible improvements in the SE community. An interface with the free software community will also be a study object.

Lastly, we will discuss the Cirandas' course from the perspective of the new developments, the software appropriation by the community, and the project sustainability, followed by our conclusions. Due to the great utilization of acronyms, a glossary containing the most frequently used ones is found at the end of the paper.

\section{Solidarity Economy in Brazil}

Considering a scenario of crisis in the capitalist model, in which an enormous number of excluded people watch the spectacular development of technology but from which only a minority derive benefits, other models of society begin to rise or become stronger. Initially, as experimentations around another possible society, these models bloom through cracks in the capitalist mode of production itself, but as they gain more and more power, sometimes becoming an option for surpassing capitalism itself.

In Brazil, especially since 2003, the Solidarity Economy movement has been growing. According to Singer (2002, p. 10), this movement can be defined as "another mode of production, whose basic principles are the collective or associated property of capital and the right to individual freedom."[1] In this mode of production, the productive units are self-managed cooperatives, where all the workers are owners and have equal voting rights in the organizations' decisions. In addition to that, the end goal is the expanded reproduction of life, not profit.

This form of organization is not new, and its origin go back to experiences which occurred in England sometime after the Industrial Revolution. From the great number of unemployed people at the time, the British Robert Owen proposed the creation of cooperative villages, the first selfmanagement experience. Despite the British government's not supporting his idea, it served as a basis for several initiatives that followed. A famous example is Charles Fourier's experience in 
France, known as phalansteries. Workers would live together in a community and the result of the work would be shared among all (Arroyo \& Schuch, 2006).

It is important, however, to point out that the so-called Solidarity Economy does not behave at present as an alternative economic system to capitalism or to centralized socialism. It would be more appropriate to talk about initiatives or solidarity economy enterprises that have great heterogeneity, and have not organized themselves yet to the point of becoming a socioeconomic model to substitute for the current models. They are experiences that escape the capitalist model logic, and nonetheless, struggle to survive within this system.

\section{The Structure of the Solidarity Economy Movement}

As a social and political movement, the Solidarity Economy movement has as its main organism the Solidarity Economy Brazilian Forum (FBES, in the Portuguese acronym). Created as a consequence of a work group of the First World Social Forum, in 2001, it has two central goals: 1) Support the strengthening of the Solidarity Economy from the base; and 2) Articulate and represent the Solidarity Economy in the elaboration of policies and in dialog with other social movements.

Connected to FBES, there are 27 Solidarity Economy State Forums and more than 120 regional forums (Cirandas, 2010). These forums are in charge of locally articulating enterprises, advisory service entities and government managers, and representing the region or the State in the national forum.

FBES has a National Coordination in which entities, national networks, and representatives of each State Forum participate in and meet twice a year. The National Coordination is supposed to articulate and represent FBES nationally. The daily policy management is done through the National Executive Coordination, which is made up of a smaller component of the National Coordination and meets bimonthly. Finally, the National Executive Department, located in Brasilia, is in charge of executing the actions planned daily by the coordinations (FBES, 2010a).

In all these spaces, participation obeys the following proportions: one fourth for advisory service entities, one fourth for public managers, and two fourths for solidarity economy enterprise representatives. This apparent imbalance is justified as long as the Solidarity Economy Enterprises (SEE) are the basis for the Solidarity Economy movement. They are the ones which effectively implement the Solidarity Economy everyday practices and support a model that seeks to escape from capitalism.

There are several kinds of SEE. The production enterprises are effectively devoted to the production of goods, which run from craftwork and agricultural products to nails and metal boards. These last ones are usually produced in recovered factories, a kind of SEE in which the exemployees of a bankrupt factory take control of the means of production and run the business in a self-managed form.

The service enterprises are cooperatives working in areas ranging from civil construction labor to free software development. A special kind of SEE in this group is the communitarian bank, which offers micro-credit and manages local currencies in communities. 
Finally, there are the consumption enterprises. These are groups of consumers that meet to make joint purchases directly from producers, restricting the production and consumption cycle within the Solidarity Economy.

important part of the SE movement are the advisory service entities. Made up of NGOs and universities, this group aims to foster the creation of SEEs and to assist those already in operation, especially through training. The NGOs in general have specific purposes such as education or research. The universities, in turn, are in charge of spreading technical/scientific knowledge among the SEE and, at the same time, producing adequate knowledge concerning the realties of these enterprises. Important entities in the universities are the Technological Incubator Programs for Popular Cooperatives (ITCPs, in the Portuguese acronym), which mainly assist at the start of an SEE life and are present in several universities in Brazil. ${ }^{[2]}$

\section{The Government and the Solidarity Economy}

Since Brazilian President Lula da Silva's first term, the government has been creating support structures for this community. Nationally, the Solidarity Economy National Department (SENAES, in the Portuguese acronym) was created, and it is subordinated to the Work and Employment Ministry (MTE, in the Portuguese acronym). At the state and local level, there are several departments that make the interface between the government and the community.

Although its simple existence represents an advance, government supports to the Solidarity Economy are generally fragile and have very low budget. Its activities are still too dependent upon the governments that are in power and managers' personal willingness to provide assistance. And they may cease to exist at any change of government. Therefore, even with significant advances, government support to the Solidarity Economy is still fragile.

In the discussions on public policy elaboration for the SE, the need for an information base on the movement's Brazilian reality is obvious. For that, a partnership between SENAES and FBES generated the mapping of the Solidarity Economy, carried out between 2005 and 2007. In this mapping, 21,859 SEEs were identified all over the country. They responded to an extensive questionnaire containing questions elaborated by a national network of entities. The results were presented in a consolidated form in the Solidarity Economy Atlas (MTE, 2010). The questions addressed economic factors such as market share and revenue, forms of management, number of workers, reasons that led to the creation of the SEE, among several others.

\section{Cirandas}

Cirandas today is the Solidarity Economy virtual community. All the movement participants have their space and can exchange information. As it is a project mandated by FBES, it is endorsed by all the community to be the Solidarity Economy meeting point on the Internet.

Cirandas was initially conceived to meet two objectives. The first is the strengthening of the SE movement as a community, using a social network to create a feeling of unity among the enterprises spread throughout Brazil. In the SE mapping (MTE, 2010), it was detected that despite there being many enterprises with characteristics that fit within the SE criteria, many of them did not consider themselves or feel part of the movement. Cirandas can become an element to contribute to the formation or strengthening of this collective identity.

The second objective is the strengthening of the SEEs themselves, offering channels of commercialization to which they would not have access without an information system geared 
specifically towards SE. According to the mapping, the majority of the SEEs are economically fragile, since in $72 \%$ of the SEEs, their participants have an income lower than half of the minimum wage. ${ }^{[3]}$ Thus, a big part of the SEEs does not cover their associates' income needs. Many enterprises are created as an alternative to unemployment or as a way to supplement income. Still according to the mapping, this is the reason for the creation of the SEE in $55 \%$ of the cases.

The success of these two objectives would result in the formation of socioeconomic networks and chains among the SE, which would reduce their dependency in relation to the capitalist market. In the SE networks, enterprises of similar or supplementary kinds meet to gain advantage, as for example through the optimization of transportation, or the sharing of sales or large consumers' services points. As to the productive chains, Solidarity Economy Enterprises buy their supplies and sell their products inside the movement, forming a closed chain inside the SE. A concrete existing example is the Justa Trama cotton chain, ${ }^{[4]}$ in which producers of cotton, fibers, fabrics and clothes are inside the Solidarity Economy.

At the same time that SEE becomes stronger, they become less dependent on the capitalist system, approaching the ideal autonomous self-sufficient Solidarity Economy model.

\section{History of Cirandas}

The development of the Cirandas started in 2007, with a public bid by Solidarity Economy National Department (SENAES) associated to the Work and Employment Ministry (MTE), at the request of the Solidarity Economy Brazilian Forum (FBES). To develop the system, a cooperative active in the free software community (Colivre) was chosen. This cooperative already sought the articulation between the SE movement and Free Software within FBES. Perceiving similar interests on the part of other clients, Colivre decided to develop a generic platform for the construction of social networks, Noosfero. ${ }^{[5]}$

Thus, Cirandas is implemented as an instance of Noosfero. Other Noosfero users contribute or have contributed to its development with resources, such as Ynternet.org (a Swiss non-profit foundation), the Software Livre.org Association, Universitas Paulo Freire (UNIFREIRE) and the Fora do Eixo Circuit (CFE).

In addition to these actors, some advisory service entities have also gotten involved in the system design, including the Technical Solidarity Lab (SOLTEC) from the Federal University of Rio de Janeiro (UFRJ), the Brazilian Institute for Social and Economic Analysis (Ibase), and CEDAC, among others.

\section{$\underline{\text { The Current State }}$}

Cirandas was officially "opened" in May of 2009, during the III ENSL - Northeastern Free Software Meeting \& IV Free Software Festival, in Bahia. Before that, it operated under the temporary name of the FBES System. The name Cirandas was chosen by means of a voting process on the FBES site.

Cirandas caters to three kinds of actors: users, enterprises, and communities. Any person can create a system user, in case he/she considers him or herself a SE sympathizer and wants to participate in the forums debates, reach other participants or buy SEE products; all he/she has to do is to register and accept the compliance terms, which includes the Solidarity Economy principles letter (FBES, 2010b). This user has a site at his/her disposal, where it is possible to publish texts, pictures and songs. 
The existing enterprises in the Cirandas are the 21,859 mapped in 2007 study. Each one has his own web page containing the SEE' name, address, contact, and the products that were available at the time. These pages were automatically created by the system. Enterprises responsibles were given an activation key, which gives access for modifying the informations, such as: contents of the page, users in the enterprise, pictures, products, etc.

While enterprises can be added by FBES according to the mapping, communities can be created by any user, and in those instances where they are open, any user can participate. Communities are intended to gather groups with specific interests, such as consumer groups or advisory service entities.

The functionalities available today do not differentiate much Cirandas from other social networks available on the Internet. The greatest difference is in the database and the search system that can find even non-activated enterprises. Below are some numbers collected on May 24, 2011:

- Users: 4033 (average increase of 5.6 users/day);

- Projects: 21,859, being 245 active (average of 2 new activation each week);

- Communities: 309 (average of 4 new community each week)

In the first 4 months of 2010 , the system had an average of 18,750 visitors per month, with a peak of 23,675 in March, possibly due to the launching of the Ecumenical Fraternity Campaign, whose central theme during March of this year was the Solidarity Economy.

\section{Cirandas and the Community}

The Solidarity Economy community, as it has been previously mentioned, is conventionally formed by enterprise members, advisory service people, and public managers. Besides these, there are the Solidarity Economy sympathizers, and individuals who identify with the purposes of the movement and eventually consume the Solidarity Economy products.

This community has several levels of interaction. The most basic and fundamental are the Solidarity Economy Regional Forums, which gather to define locally the movement courses and actions. They are in charge of organizing fairs, training activities, and organize the basis for discussions at state and national levels. These fairs are also a very important space for gettogethers, debates, selling and exchanges among the movement's members.

Despite some attempts to involve the Solidarity Economy community in the conception and development of the system, the participation level was very low. In general, the theme information technology is not attractive to the community and it was never considered a priority in the movement. In addition to that, the dispersion of the movement throughout a country of continental dimensions and the lack of resources for the system development made the participation process difficult. However, the carrying out of workshops with this purpose could have attracted the community to discuss the system.

In relation to the Cirandas virtual community, it is important to point out that, contrary to the SE real community, where there is no material proof of participation, the Cirandas registration forces a person to formally participate in a virtual community. Thus it should be noted, that the virtual community strengthens the real community, since it turns a previously dispersed and nonformalized bond into a formal one. 
On the other hand, the joining of new members in the real community occurs by means of a social validation, where each individual is recognized by the work he/she carries out within the community. This social validation does not exist in the virtual community, and it is possible that some of the Cirandas' users don't know what Solidarity Economy means, in the instance where they have not read the terms of compliance.

\section{Does Cirandas strengthen the Solidarity Economy community?}

A first way of analyzing if Cirandas strengthens the SE community would be through the Social Capital concept, since this relationship among virtual social networks and social capital has been widely studied. According to Bourdieu (1986, p. 248), "social capital is the aggregate of the actual or potential resources which are linked to possession of a durable network of more or less institutionalized relationships of mutual acquaintance and recognition". That is, they are resources a person may have access to out of the relationships he/she maintains. These may be family relationships, with friends, co-workers, etc. Still according to Bourdieu, the amount of a person's social capital depends on the size of the network maintained and the amount of resources held by the people in his/her network.

In this sense, there emerges the question whether Cirandas as a Social Network Service reinforces the social capital of the community's members. To answer this question two elements can be analyzed. First, the size of the network in which each takes part. We should ask the following question about this: does Cirandas effectively increase each of its members' networks? Second, the amount of resources it can mobilize on behalf of each member. In this sense, the question would be whether this network can be realized in material and objective elements.

What we have so far is that Cirandas enables SEE workers to establish new relationships and thereby have access to new resources. Through Cirandas they can buy cheaper raw materials (by making joint purchases among several ventures), contact advisory service organizations to obtain help, sell their products more easily through the site available for them on Cirandas, etc. Cirandas leverages their network expansion through new relationships, permitting access to more resources.

Another important point is how Cirandas can help the Solidarity Economy movement, and specifically the SEEs. Cirandas as an informatics system can contribute to the organization of the movement, assist with information exchange and systematization, support transparency in the relations among all the members, and act as an enabling tool for operations such as commercialization and certification.

On the other hand, many SEEs do not consider an information system as a priority for the movement. One of the reasons is that only a small minority of the SEEs and people from the movement have, or at least have easy access to the Internet. The digital inclusion of its members is an issue that has been dealt within the movement, but Cirandas will barely cause a great impact on the movement until it is solved.

As with any other technology, an information system is not a neutral element. It encourages certain forms of organization. According to Marques (2005), every technology is developed within a certain "reference framework". This is so because it is never possible to take into account all the factors and actors in determining a solution. Thus, choices are made and certain elements are disregarded. The problem is that these choices are essentially political as they have an impact on power distribution. 
An information system not only is influenced by its developers in its initial design, but will also influence the form of organization and the way networked enabled relations will take place among its users. For that reason, it is important to evaluate elements such as what kind of uses Cirandas allows, what kind of behavior Cirandas can encourage in its community, and what social values it reproduces or faces, as suggested by Granqvist (2005).

However, while Granqvist (2005) raises questions about how technology influences users, Williams and Durrance (2008) expand the debate with three questions: does technology shape social networks (social networks in a wider sense, and not simply on line social networks)? Do social networks shape technology? Or do they shape each other? According to our understanding, they shape each other. On the one hand, Cirandas was shaped according to what was supposed to be the needs of the Solidarity Economy network. The enterprises initial database was an outcome of the community's initiative; therefore we can say that the community has shaped the technology. On the other hand, in the case where the system goals are met, certain relationships within the community will clearly be shaped by the technology. That is, the system can help establish networks and productive chains turning Solidarity Economy into a feasible production model.

Another important element to be considered is the social networks as a socio-technical arrangement (assemblage), which hybridizes the social and the technical. According to Arnold (2007), it is not possible to separate the characterization of virtual network from that of the communities, that is, from the system and the network of people which it produces. This author criticizes the dichotomy created between technology and society, which sets forth that technology can make it easier, or even cause changes from a real society to a desired one. According to him, in the a-modern paradigm, technology alters both the real society and the desired one: "The amodern question is not how to assess and maximize the good use of ICTs (Information and Communication Technologies) in communities, but how ICTs in communities are changing what good is" (Arnold, 2007, p. 4).

Cirandas' implementation and effective use in the SE community can bring great changes to the SEEs daily life. The simple practice of developing a website brings about much reflection on the part of the entrepreneurs. If it is decided to publish the business' history, it will be necessary to recall all the elements that led to the carrying out of the initiative. By inserting pictures of the products, their appearance will have to be thought through. By publishing the supplies and the open price list, the workers will have to think about the product price composition, and thus understand and optimize their production.

Finally, we can say that Cirandas can strengthen the Solidarity Economy community. Whether it is by offering new business channels or forcing a reflection about the business management, the use of the system will introduce the SEEs to the modern society paradigm, in which a significant part of the social and economic relations go through virtual means.

\section{Interaction with the Free Software Community}

Another factor that must be pointed out in the Cirandas development process was the interaction with the Free Software community. This community, created in the 1980s, advocates for the software freedom of use expressed in 4 principles (GNU, 2010):

"The freedom to run the program, for any purpose (freedom 0).

The freedom to study how the program works, and adapt it to your needs (freedom 1). Access to the source code is a precondition for this. 
The freedom to redistribute copies so you can help your neighbor (freedom 2).

The freedom to improve the program, and release your improvements to the public, so that the whole community benefits (freedom 3). Access to the source code is a precondition for this."

This philosophy, freedom above all, is strongly based on solidarity and therefore is directly related to the Solidarity Economy movement. It is obvious that any initiative that involves ICTs and SE must be taken according to the Free Software patterns. However, these movements are not completely in agreement. Despite abolishing the intellectual property concept about the source, the Free Software movement does not question the capitalist production model based on workers' exploitation and the search for profit. Thus, we can say that software for the Solidarity Economy must be free software, but an enterprise that develops free software does not necessarily fit with the solidarity economy principles.

The Cirandas' development history is fundamentally linked to the interface between these two movements. The first step in promoting the meeting of members of both movements was the creation of a collaborative page (wiki) in which several Free Software and Solidarity Economy integration possibilities were listed (Ecosolivre, 2010). In this page, we can find a synthesis of the desire for synergy between the movements (Ecosolivre, 2010):

The integration among the free software and Solidarity Economy movements seems to be a promising tendency for both, to the extent that solidarity economy enterprises strengthen themselves by increasing the use of free technologies (particularly in the Information Technology field), and professionals that operate in the free software field begin to organize themselves in social economic enterprises which provide products, services and support in information technology to the Solidarity Economy organizations.

In fact, the process took place as follows: a free software production cooperative was created, which operates within the Solidarity Economy principles. It operates in the construction of the Cirandas system in partnership with FBES. Unfortunately, these kinds of initiatives are still very rare. Computing professionals are quickly absorbed by the traditional market, and rarely suffer the marginalization that leads people to create Solidarity Economy enterprises. However, this kind of initiative, ideologically driven, should be encouraged and presented as a feasible option to strengthen the Solidarity Economy community.

\section{The Future of Cirandas}

The continuation of the Cirandas project went through several operating phases, which can be divided into three groups: development, that is, design and implementation of new functionalities which addresses the issues covered in this article; appropriation of the system by the community, an area in which there is still a lot to be done; and finally funding and sustainability, a recurrent concern for the Cirandas project.

\section{New Functionalities}

Based on the number of system users, we can affirm that Cirandas is already consolidated as an alternative social network. In this, the major goal becomes the implementation of economic functionalities, which will indeed make the system reach the objectives it proposes. The system itself offers a community where new functionalities can be discussed (Cirandas, 2010b).

At present, new functionalities are being modeled and developed. They will enable the development of networks and chains with the help of Cirandas. To do that, a database of products 
and services offered by the SE is being created. This allows for the inclusion of supplies, equipment and knowledge used by each product or service offered by a SEE. In so doing, computational intelligence algorithms can suggest interactions between SEEs which offer and use certain supplies, and equipment and knowledge sharing. This will be done based on geographic proximity and economic sector criteria.

The creation of a tree of products and services will contribute to a unified classification of everything that is commercialized in the SE. This category database will be available to the public so as to permit other sites to communicate with Cirandas using the same classes. In addition to that, future webservices will have a fundamental role in integrating the system with other community and government portals.

Another kind of integration that can be taken into account is between Cirandas and enterprise resource planning systems (ERPs) developed for the Solidarity Economy. Thus, as the workers control their enterprises through an ERP (stock, cash flow, projects, etc.) they can synchronize data directly with Cirandas for publishing and other purposes.

Finally, one of the goals is the adaptation of Cirandas to the National Fair and Solidarity Trade System (SNCJS, 2010). The first step here is the presentation of an open spreadsheet that shows the price composition of each product or service. In general, the system will evolve towards the strengthening of economic functionalities, considering that the social aspect is already well established.

\section{Appropriation of the system by the community}

Cirandas today is already present at the majority of events related to the Solidarity Economythere would be a lecture on the system, a tent with information or even training workshops.

Future proposals point out to the creation of qualified telecenters, that is, environments with infrastructure to access the Internet where there are people trained to offer support to Cirandas registered members. The telecenters network in Brazil today is quite comprehensive and its utilization by the Solidarity Economy community tends to strengthen the use of Cirandas.

It is interesting to remember that, in most cases, the qualification for using Cirandas follows a basic computer training. This is due to the low rate of users that are able to use computers within the Solidarity Economy community. It follows that, the system appropriation strategies by the community should begin with basic computer training, in addition to training on Solidarity Economy principles themselves.

As these training strategies in any field of the Solidarity Economy are usually implemented using popular education methods, Cirandas has a strong relation with the Community Informatics $(\mathrm{Cl})$ concept proposed by Stoecker (2005): "a sustainable approach to community enrichment that integrates participatory design of information technology resources, popular education, and assetbased development to enhance citizen empowerment and quality of life." The basic computer training itself denotes a concern to consider the student's reality, and with his/her help, to work on questions related to Cirandas.

\section{Project Sustainability}

The continuation of the Cirandas project is directly related to its capacity to obtain financial resources. There are permanent costs, which include bug correction and server maintenance, 
besides other development and training costs. Such financing has always been achieved through public bidding with funding agencies such as Finep and the Marista Solidarity Institute. This kind of strategy tends to make system development fragile, since funding is uncertain both in the amount of resources and as to the time when resources are released. As a result, any kind of planning is difficult, being subject to political imperatives.

The system's self-sustaining option does not seem feasible at the moment. Charging a fee for the use of Cirandas would be a valid option, but before that, the system should be efficient and really capable of generating income for the solidarity economy enterprises. Upon reaching this phase, requesting that the enterprises contribute proportionally to the value of the available products would be a reasonable way to maintain the system and improve operational planning. Since this is not yet possible, system development will likely occur by means of public bidding and, eventually, through the volunteer work of free software communities.

\section{Conclusions}

In this article, we have analyzed the development of the Cirandas tool from the perspective of the community for which the system was developed. We have highlighted aspects of the creation of a virtual community based on a real community and the relations that evolve form both of these.

In general, we can affirm that Cirandas is not directly responding to a demand from the community, which has more urgent and material needs. However, its development can be understood as a natural adaptation of the community inserted in a society where the ICTs are part of their everyday lives, even for those who are left out of the process.

Even though it is not an urgent need, we have evaluated in which ways Cirandas contributes to strengthening the community and increasing its social capital. A community spread throughout Brazil, which wishes to strengthen itself to the point of becoming an alternative to the capitalist model, cannot put ICTs aside in its articulation. Cirandas should play this role, which will only be really effective from the moment the community reaches a participation level that can lead to the production of a system that can directly and appropriately respond to its needs.

\section{Glossary}

Cl: Community Informatics

FBES: Fórum Brasileiro de Economia Solidária - Brazilian Solidarity Economy Forum

ICTs: Information and Communication Technologies

SE: Solidarity Economy

SEE: Solidarity Economy Enterprise

SENAES: Secretaria Nacional de Economia Solidária - National Solidarity Economy Department

\section{Bibliography}

ARNOLD, M. (2007). The concept of community and the character of networks. The Journal of Community Informatics, v. 3, n. 2.

ARROYO, J. C. T., \& SCHUCH, F. C. (2006) Economia Popular e Solidária: A alavanca para um desenvolvimento sustentável. São Paulo: Fundação Perseu Abramo. 
BOURDIEU, P. (1986). The forms of capital. In RICHARDSON, J. (Ed.). Handbook of Theory and Research for the Sociology of Education. Westport, CT: Greenwood Press.

CIRANDAS. (2010). Espaço Cirandas. Retrieved May 10, 2010 from http://www.cirandas.net/.

CIRANDAS. (2010b). Futuro do Cirandas. Retrieved May 10, 2010 from http://cirandas.net/ajuda/futuro/futuro-do-cirandas-o-que-vem-por-ai.

ECOSOLIVRE. (2010). Sítio Wiki da Rede EcoSoLivre. Retrieved May 10, 2010 from http://wiki.softwarelivre.org/EconomiaSolidaria/WebHome.

FBES (2010a). Site do Fórum Brasileiro de Economia Solidária. Retrieved May 10, 2010 from http://www.fbes.org.br/.

FBES (2010b). Carta de Princípios da Economia Solidária. Retrieved May 10, 2010 from http://www.fbes.org.br/index.php?option=com content\&task=view\&id=63\&ltemid=60

GNU (2010). Projeto GNU. Retrieved May 10, 2010 from http://www.gnu.org/.

GRANQVIST, M. (2005). Looking Critically at ICT4Dev: The Case of Lincos. The Journal of Community Informatics, v. 2, n. 1, pp. 21-34.

MTE. 2010. Atlas da Economia Solidária. Secretaria Nacional de Economia Solidária. Retrieved May 10, 2010 from http://www.mte.gov.br/sistemas/atlas/atlases.html.

NOOSFERO. 2010. Site da Plataforma Web Noosfero. Retrieved May 10, 2010 from http://www.colivre.coop.br/Noosfero/WebHome.

SINGER, P. (2002). Introdução à Economia Solidária. São Paulo: Editora Perseu Abramo.

SNCJS 2010. Sistema Nacional de Comércio Justo e Solidário. Retrieved May 10, 2010 from http://www.mte.gov.br/ecosolidaria/prog organizacao sistema.asp.

STOECKER, R. (2005). Is Community Informatics good for communities? Questions confronting an emerging field. The Journal of Community Informatics, v. 1, n. 3, pp. 13-26.

WILLIAMS, K., \& DURRANCE, J. (2008). Social Networks and Social Capital: Rethinking Theory in Community Informatics. The Journal of Community Informatics, v. 4, n. 3.

\section{[1] Authors' translation}

[2] According to the Unicamp ITCP site, 44 universities take part in the ITCPs network currently. For a complete list, see http://www.itcp.usp.br/drupal/node/440.

[3]At the time the mapping was done (2005 to 2007) the Brazilian minimum monthly wage varied from US\$ 150.00 to US\$190.00 (http://www.mte.gov.br/sal min/EVOLEISM.pdf).

[4] http://www.justatrama.com.br

[5] http://noosfero.org 